\title{
The parathyroid oxyphil cells
}

\author{
A. C. CHRISTIE
}

From the Wollongong Hospital, Wollongong, N.S.W., Australia

SYNOPSIS A semi-quantitative study of the parathyroid oxyphil cells in over 500 cases is presented. They are divided into two age groups: under 45 years of age and over that age period. In the former group the oxyphil cells are few in number except in advanced renal disease when there is a gross increase; in one case the increase was at least 1,200 -fold. Over 45 years of age there is an average increase but a considerable number of cases, including some in the ninth decade, show no significant increase. From approximately the middle of the fifth decade onwards the average increase is greater in females than males, roughly twice or even more for all decades.

Although at all ages the greatest average increase occurs in cases showing azotaemia, other cases demonstrating either minimal or no significant histological evidence of chronic renal disease in routine histological sections show a considerable increase in oxyphil cells. It is postulated that the oxyphil cells are most likely called in to elaborate a hormone as a defence mechanism to maintain the equilibrium of certain as yet undetermined biochemical constituents. A plea is made for a more accurate assessment of these cells in various disease states. A simple method is outlined for making a quantitative assessment of the number of oxyphil cells.

A preliminary investigation of the extent of proliferation of the oxyphil cells in various diseases strongly suggests that significant differences may be present.

Finally attention is drawn to the fact that in the rare situation, but now likely to be more frequent, where a partial parathyroidectomy follows renal transplantation it will be possible to ascertain what happens to the oxyphil cells following relief of the azotaemic state. Correlation of the histological changes with alterations of electrolyte and acid base studies may well elucidate the significance of these cells.

Although mentioned by Sandström (1880) and described in greater detail by Welsh (1898), the oxyphil cells in the parathyroid glands have received little attention in the intervening period. Christie (1961) reviewed the literature relating to these cells and, in addition, reported 13 cases showing hyperplasia of them.

Histochemical studies suggest that the relatively coarse eosinophil or oxyphil granules in the ctyoplasm of these cells are composed, in part at least, of phospholipid, a property in common with the acidophil cells of the anterior pituitary gland (Christie, 1955). More recently Tremblay and Pearse (1959) have studied certain enzyme systems in these cells. Although recorded by some workers as nonfunctional and products of involution there is little cytological evidence to suggest this. However, in contrast to principal cell adenomata, the few case reports of oxyphil cell adenomata do not record any

Received for publication 24 January 1967. associated specific clinical syndrome. Nevertheless these cells are increased in number, often greatly so, in hyperplastic glands secondary to advanced renal disease.

It is the purpose of this paper to make a more detailed study of these cells in various diseases.

\section{METHODS AND MATERIAL}

Parathyroid glands were located and dissected out in almost 600 cases. The glands were fixed in $10 \%$ formolsaline and standard paraffin sections stained by haematoxylin and eosin were prepared. A detailed histological study was made of the glands, only cases in which three or more glands were located being included in the series. In particular, the following points were noted: (1) the absolute size of the glands; (2) the presence or absence of fat (absence of fat is considered an early sign of hyperplasia, Castleman and Mallory, 1935); (3) the predominant cell type.

The presence or absence of water clear (Wasserhelle) cells was also noted. It is apparent that various gradations 
between vacuolated principal cells and water clear cells are frequently found.

(4) A quantitative assessment was made of the number of oxyphil cells by measuring the diameter in microns of each group of such cells in sections taken through the maximum diameter of each gland and summating the areas thus obtained by the formula $\pi \mathrm{a} b$ where $\mathrm{a}$ and $\mathrm{b}$ represent one half of each major and minor axis respectively.

Although it would be more accurate to count each oxyphil cell in each gland and assess the degree of increase as a sum total thus obtained, it is obvious that such a laborious procedure would be impracticable, for it would involve counting cells in serial sections. As each section is $7 \mu$ thick a gland only $3.0 \mathrm{~mm}$. thick would involve counting cells in over 400 serial sections, and many more sections in hyperplastic glands. The system adopted is simple and accurate and only requires an eye piece micrometer in addition to the standard laboratory microscope.

In this paper the selection of material has been considered important in assessing hyperplasia. Only cases in which three or more glands were located have been included. When the oxyphil cells were not generally increased but were confined to one large clump in one gland, this was recorded separately as an adenoma (Table V). This is important because one can never be certain that all the parathyroid tissue has been located in any particular case, for an adenoma may well occur in an aberrant fifth or even sixth gland, which, although not particularly common, are known to occur in sites extending from the tonsil to the aortic arch (Gilmour and Martin, 1937). Apart from this limitation to cases in which three or more glands were located no selection was made; although, as mentioned above, adenomata have been recorded separately.

Whilst it is not the primary purpose of this paper to deal with cytological and histochemical studies some findings, including unpublished original work, have been included where necessary.

\section{RESULTS}

Table I shows the effects of various simple fixatives in preserving the oxyphil cell granules. A comparison is made with the granules of the Paneth cells in the intestine and also the small granules in the argentaffin (Kultschitzky) cells also present in the intestine. Baker (1950) employed these simple
TABLE I

EFFECT OF FIXATIVES IN PRESERVING GRANULES

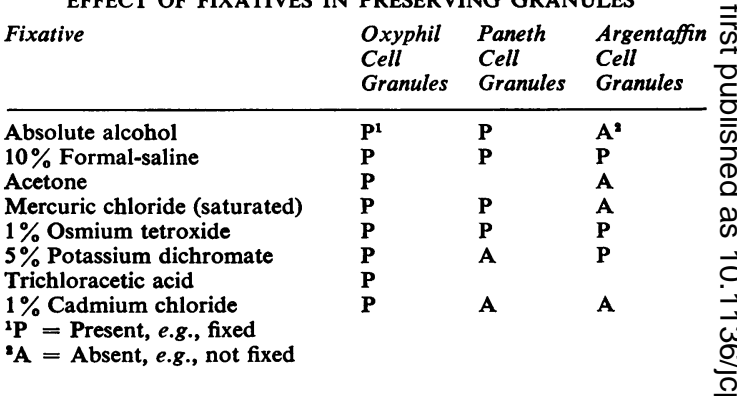

fixatives to distinguish whether substances be protein or lipid in nature. It will be seen that all the fixatives. employed preserve the oxyphil granules, thus suggest- $-\vec{i}$ ing that they are composed of lipid and protein moieties. The fact that they are well stained by Baker'so acid haematin stain for phospholipid (Christie, 1955) ${ }_{-}$ suggests that they are a phospholipid, and, in the light of the above findings, probably a phospholipid $\stackrel{\subseteq}{<}$ protein complex, being similar in this respect to $\vec{\theta}$ granules in the pituitary acidophil cells.

Table II summarizes additional, as yet unreported, staining properties of these cells. In this case theo pituitary acidophil cell granules and intestinal argentaffin cell granules are included for comparison.

Figures 1 and 2 show a grading according to age $\frac{\varnothing}{\varnothing}$ and sex of 510 cases (308 males and 202 females). There were 48 cases less than 40 years of age in fourō of which there was a great increase of oxyphil cells. All four of these cases showed advanced renal disease (Table III). The remaining 44 cases showed? an average of $15 \times 10^{3}$ sq. $\mu /$ gland with a maximumo of $70 \times 10^{3} \mathrm{sq} . \mu$. From 40 to 45 years of age there is, in general, little increase of oxyphil cells. However, a few cases (one male and three female) showed å mild increase. From 45 years of age onwards there is $₹$ confirmation of the findings of previous workerso that the oxyphil cells increase in number with age (Anderson, 1953). However, this is not invariably so; in fact, approximately $46 \%$ of males and $33 \%$ of females over the age of 45 years in the above series only show a minimal or no increase (less than 0 $100 \times 10^{3}$ sq. $\mu /$ gland $)$. In this series 65 (46 males and

TABLE II

STAINING PROPERTIES OF OXYPHIL CELL GRANULES

Pituitary Acidophil Cell Granules

Argentaffin Cell Granules

$\begin{array}{lll}\text { Strongly eosinophilic } & \begin{array}{l}\text { Strongly eosinophilic } \\ \text { Strongly positive }\end{array} & \begin{array}{l}\text { Eosinophilic } \\ \text { Sositive }\end{array}\end{array}$

Haematoxylin and eosin (Welsh, 1898)

Baker's acid haematin stain for phospholipid (Christie, 1955)

Luxol-fast blue-neutral red stain for phospholipid

Hexamine-silver nitrate

Ferric-ferricyanide method of Schmorl

Blue tetrazolium

Gomori's aldehyde fuschin

Arginine (Sakaguchi's test)

Osmium tetroxide reduction

Positive

Negative

Negative

Deep brown

Negative

Negative

Nil

Positive

Negative

Negative

Deep brown

Positive

Positive

Negative

Deep blue

Negative

Negative

Nil

Strongly positive 


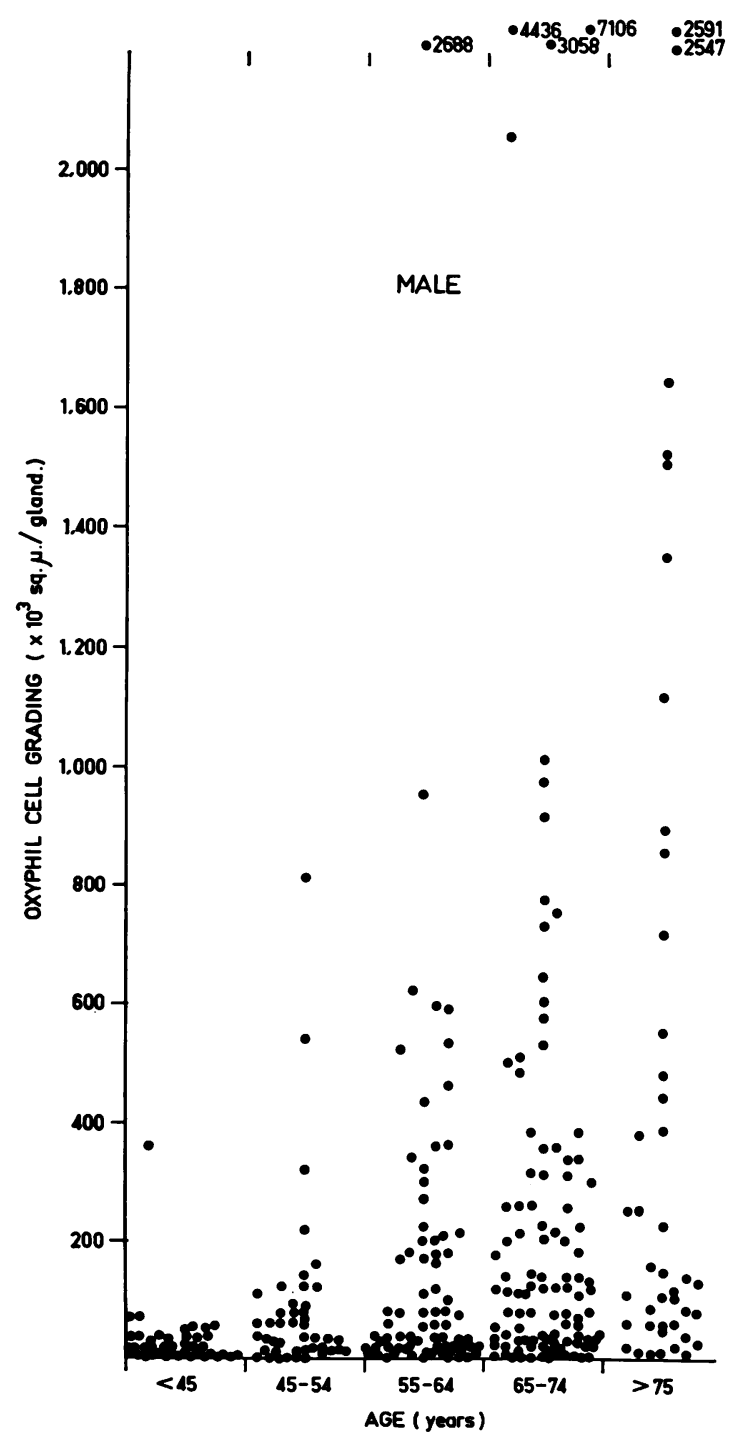

FIG. 1. Age distribution of oxyphil cell areas in males.

19 females) out of 154 cases (that is $42 \%$ ) 70 years of age and over showed a grading of less than $100 \times 10^{3}$ sq. $\mu /$ gland. The post-mortem findings in the 65 cases showed a wide variety of lesions with no preponderance of any one pathological condition. In these elderly cases renal lesions of mild degree, mainly pyelonephritis, interstitial nephritis, and hypertensive nephrosclerosis were common. In over $50 \%$ of these 65 cases the blood urea level was over $50 \mathrm{mg} . \%$.

Table IV gives the mean values for oxyphil cell areas per gland in the fifth and subsequent decades

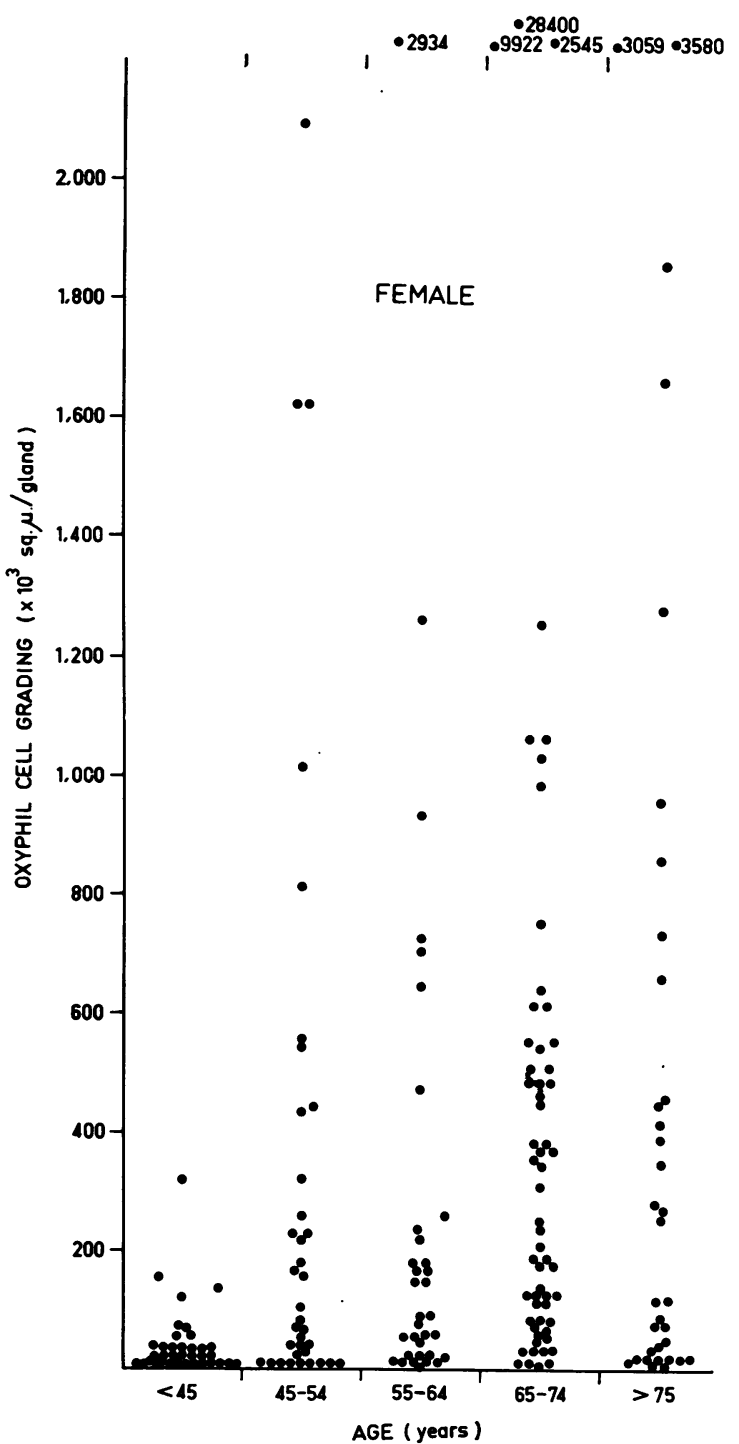

FIG. 2. Age distribution of oxyphil cell areas in females.

for each sex. In each decade the female score varies from double to more than triple the male score.

Table III lists the cases of advanced renal disease as assessed both by the blood urea and histological appearances of the kidneys. In these cases there is general principal cell hyperplasia, oxyphil cell hyperplasia, and the appearance of a number of groups of vacuolated principal cells showing all gradations to water clear cells. This histological pattern has already been fully described by Castleman and Mallory (1935).

However, other cases show indisputable evidence 
TABLE III

CASES OF ADVANCED CHRONIC NEPHRITIS

\begin{tabular}{|c|c|c|c|c|c|c|}
\hline Case & Age & Sex & $\begin{array}{l}\text { No. of } \\
\text { Glands }\end{array}$ & $\begin{array}{l}\text { Weight } \\
\text { of Glands } \\
\text { (mg.) }\end{array}$ & $\begin{array}{l}\text { Blood Urea } \\
\text { (mg./100 ml.) }\end{array}$ & $\begin{array}{l}\text { Oxyphil Cell } \\
\text { Grading } \\
\left(\times 10^{3}\right. \\
\text { sq. } / \text { /gland })\end{array}$ \\
\hline 1 & 74 & $\mathbf{M}$ & 3 & $\begin{array}{l}\text { Slightly } \\
\text { enlarged }\end{array}$ & 240 & 4,436 \\
\hline 2 & 30 & $\mathbf{F}$ & 4 & 4,500 & 266 & 62,007 \\
\hline 3 & 37 & $\mathbf{M}$ & 4 & Enlarged & 120 & 3,900 \\
\hline 4 & 64 & $F$ & 4 & 610 & 400 & 2,934 \\
\hline 5 & 28 & $\mathbf{M}$ & 4 & 1,300 & 260 & 262 \\
\hline 6 & 33 & $\mathbf{F}$ & 4 & 5,200 & 120 & 10,549 \\
\hline
\end{tabular}

TABLE IV

AVERAGE OXYPHIL SCORES FOR EACH DECADE

\begin{tabular}{lcccc}
$\begin{array}{l}\text { Oxyphil Cell Scores } \\
\left(\times 10^{3} \text { sq. } / \text { /gland }\right)\end{array}$ & \multicolumn{5}{c}{ Decade } & & \\
\cline { 2 - 5 } & $40-49$ & $50-59$ & $60-69$ & $70+$ \\
\hline Male & 35 & 151 & 286 & 333 \\
Female & 201 & 315 & 634 & 1,026
\end{tabular}

of oxyphil cell hyperplasia without evidence of concurrent principal cell hyperplasia as in the following two cases.

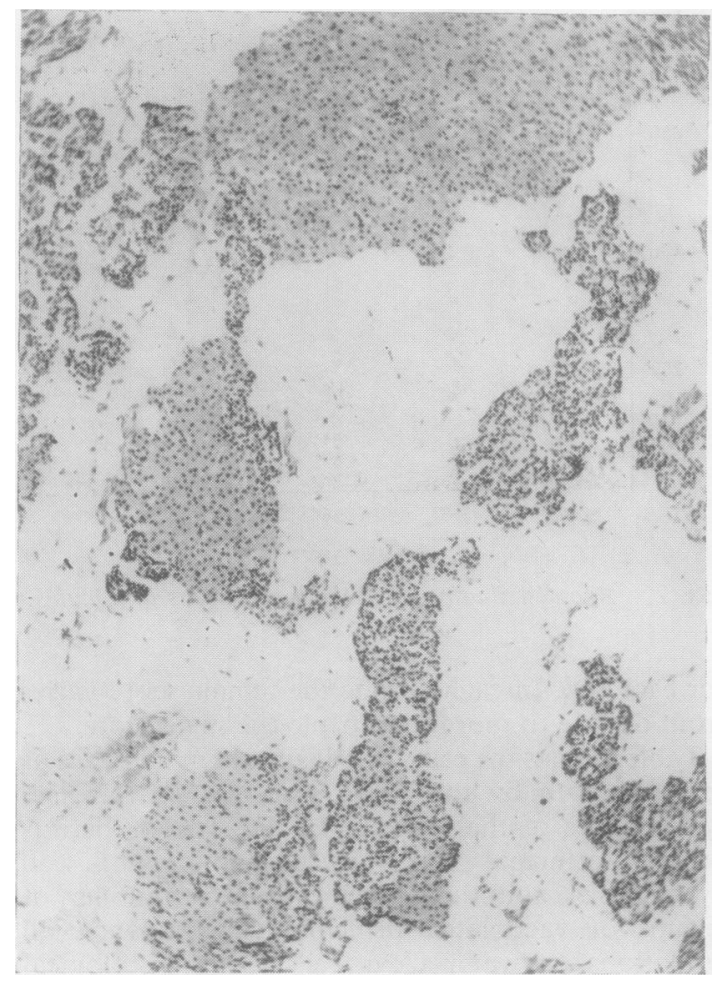

FIG. 3. Mrs. M. E. A general view of one gland showing three large compact nodules of oxyphil cells in a gland showing no evidence of principal cell hyperplasia. $\times 26$.
CASE 1 (FIG. 3) Mrs M. E. aged 48 years. Advanced inoperable carcinoma of the cervix was diagnosed in October 1957 and treated by radium. The blood urea level at that time was $36 \mathrm{mg}$. per $100 \mathrm{ml}$. (Many estimations over several weeks gave values in this range.) The neoplasm recurred with clinical evidence of ureteric obstruction and, in December, 1958, the left ureter was transplanted into the sigmoid colon.

In July 1959 there was radiological evidence of "fairly marked hydronephrosis of the right kidney and very little apparent function of the left kidney'. In August, 1959 the blood urea level was $49 \mathrm{mg}$. $/ 100 \mathrm{ml}$. blood. The blood pressure was $110 / 60 \mathrm{~mm}$. mercury. In October 1959 the blood urea level rapidly rose to $229 \mathrm{mg} . / 100 \mathrm{ml}$. and five days later, one day before death, was $158 \mathrm{mg}$. $/ 100 \mathrm{ml}$.

Four parathyroid glands of normal size were located is and examined. As Fig. 3 shows, there is a liberal admixture is of fat in the parenchyma, a pattern indicating the absence of even of early general hyperplasia (Castleman and Mallory, 1935). The dark principal cell predominates. Water- 은 clear and vacuolated principal cells are absent. Numerous hyperplastic nodules of oxyphil cells measuring up to $1.25 \mathrm{~mm} . \times 0.75 \mathrm{~mm}$. are dispersed throughout all four glands. Figure 3 shows three such nodules of variable

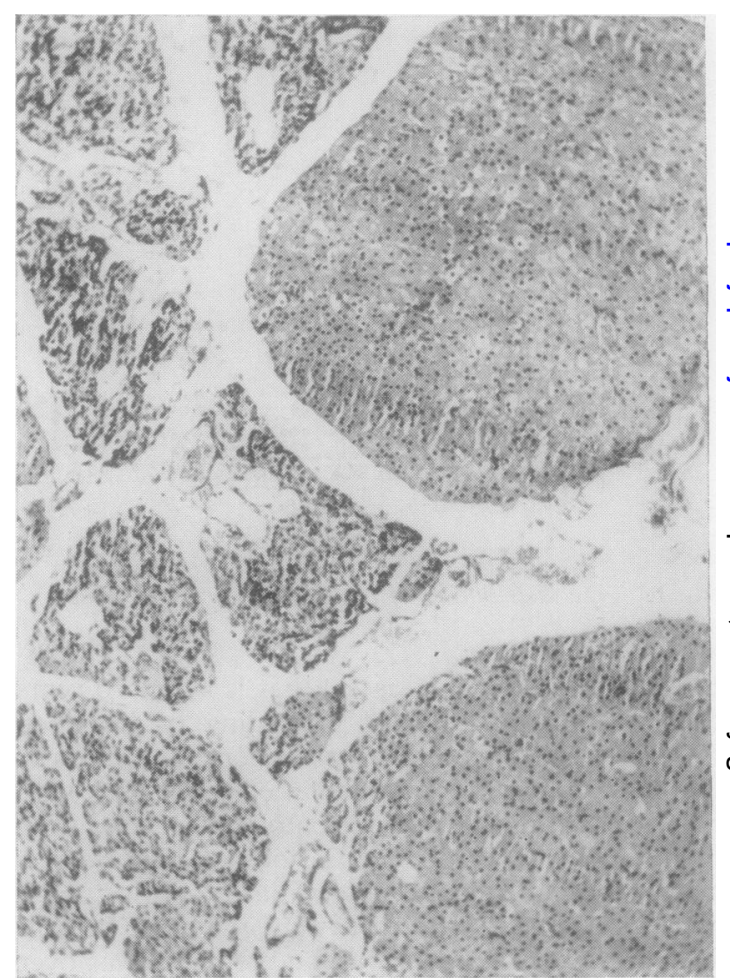

FIG. 4. Mr. H. M. Portion of two large hyperplastic nodules of oxyphil cells in a gland showing no other $\bigcirc$ evidence of hyperplasia. $\times 46$. 
size within the substance of one gland. The oxyphil cell grading is $1,617 \times 10^{3}$ sq. $\mu /$ gland.

CASE 2 (FIG. 4) Mr. H.M., aged 76 years, bilateral pulmonary silicosis was diagnosed 10 years ago. Blood pressure was $140 / 60 \mathrm{~mm}$. mercury. Haemoglobin, serum calcium, phosphorus, protein, and alkaline phosphatase values were normal. Blood urea levels in the six months before death ranged from 56 to $65 \mathrm{mg} . / 100 \mathrm{ml}$.

Four glands of normal size were located. On section each shows a moderate amount of enmeshed fat, except in the numerous hyperplastic nodules of oxyphil cells. The principal cells show no evidence of hyperplasia. They are of the small dark variety, there being only an occasional vacuolated cell and no water clear cells. The oxyphil cell score is $2,591 \times 10^{3}$ sq. $\mu /$ gland.

In both cases all the hyperplastic groups of oxyphil cells are well vascularized with open capillaries filled with blood. They are also composed of an intimate mixture of pale and dark cells in variable proportions. As shown by Christie (1955), the dark oxyphil cells are more concentrated aggregations of phospholipid granules, whereas the pale cells are relatively granule-impoverished, most likely as a result of secretory discharge.

Although this paper is mainly concerned with glands showing hyperplastic nodules, all relatively large solitary oxyphil cell groups were also noted. The difference between adenoma and hyperplasia of the oxyphil cells is fundamentally an application of the distinction drawn by Castleman and Mallory (1935) between adenomata and hyperplasia of principal cells, namely, an adenoma is a solitary collection and hyperplasia is a generalized increase in all the glands.

Table V tabulates 19 such oxyphil cell adenomata of variable size (but usually small) ranging up to $7.0 \times 5.0 \mathrm{~mm}$. in diameter in case 17. It is of interest to note that 12 are in females. As these 19 lesions were selected from 530 cases with a male:female ratio of $312: 218$, when corrected for an equal sex distribution the preponderance is almost 3:1.

Figure 5 shows in graphic form the distribution of oxyphil cell areas in cases plotted against blood urea levels. If the blood urea is to be used as an indicator of chronically impaired renal function it is important to accept only those values taken at least three to four weeks before death, as the blood urea level can rise rapidly just before death without being a true indicator of chronic renal disease.

From the Table it will be seen that 131 out of 195 cases $(67 \%)$ fall within the area indicating oxyphil areas less than $400 \times 10^{3} \mathrm{sq} . \mu /$ gland and urea levels below $151 \mathrm{mg} . \%$ per $100 \mathrm{ml}$. blood. At the top of the graph there are 11 cases with varying blood urea levels up to and actually exceeding $350 \mathrm{mg} . \%$ and
TABLE V

\begin{tabular}{|c|c|c|c|}
\hline \multirow[b]{2}{*}{ Case } & \multicolumn{3}{|r|}{ ADENOMATA OF OXYPHIL CELLS } \\
\hline & Age & $\operatorname{Sex}$ & Clinical and Post-mortem Data \\
\hline 1 & 32 & $\mathbf{M}$ & Acute leukaemia \\
\hline 2 & 70 & $\mathbf{F}$ & $\begin{array}{l}\text { Old myocardial infarct; congestive cardiac } \\
\text { failure and chronic pyelonephritis }\end{array}$ \\
\hline 3 & 62 & $\mathbf{F}$ & Thyroid enlargement, fibro-adenoma of ovary \\
\hline 4 & 62 & $\mathbf{M}$ & $\begin{array}{l}\text { Essential hypertension, emphysema, gastric } \\
\text { ulcer }\end{array}$ \\
\hline 5 & 51 & $\mathbf{F}$ & Cerebral haemorrhage \\
\hline 6 & 46 & $\mathbf{F}$ & $\begin{array}{l}\text { Pontine haemorrhage, hypertensive cardio- } \\
\text { vascular disease, chronic duodenal ulcer }\end{array}$ \\
\hline 7 & 54 & $\mathbf{F}$ & $\begin{array}{l}\text { Carcinoma left breast with metastases } \\
\text { (including spinal); slightly obese }\end{array}$ \\
\hline 8 & 71 & $\mathbf{F}$ & $\begin{array}{l}\text { Massive pulmonary embolus; left femoral } \\
\text { thrombosis; severe myocardial fibrosis, coronary } \\
\text { atherosclerosis and cholelithiasis }\end{array}$ \\
\hline 9 & 59 & $\mathbf{M}$ & $\begin{array}{l}\text { Carcinoma of liver with metastases; small } \\
\text { solitary oxyphil cell adenoma } 0.8 \mathrm{~mm} \text {. in } \\
\text { diameter in one gland }\end{array}$ \\
\hline 10 & 70 & $\mathbf{F}$ & Acquired haemolytic anaemia \\
\hline 11 & 68 & $\mathbf{M}$ & $\begin{array}{l}\text { Hypertensive nephrosclerosis; unilateral } \\
\text { chronic pyelonephritis }\end{array}$ \\
\hline 12 & 67 & $\mathbf{M}$ & $\begin{array}{l}\text { Lobar pneumonia, myocardial fibrosis, } \\
\text { coronary atherosclerosis, cardiac failure }\end{array}$ \\
\hline 13 & 65 & $\mathbf{M}$ & $\begin{array}{l}\text { Hydronephrosis due to prostatic obstruction; } \\
\text { myocardial infarction; obese }\end{array}$ \\
\hline 14 & 47 & $\mathbf{F}$ & $\begin{array}{l}\text { Chronic cholecystitis; chronic biliary } \\
\text { cirrhosis }\end{array}$ \\
\hline 15 & 75 & $\mathbf{F}$ & $\begin{array}{l}\text { Diabetes, cirrhosis of liver, chronic } \\
\text { nephrosclerosis }\end{array}$ \\
\hline 16 & 72 & $\mathbf{F}$ & Carcinoma of peritoneum \\
\hline 17 & 65 & $\mathbf{F}$ & $\begin{array}{l}\text { Cerebral haemorrhage, hypertensive } \\
\text { cardiovascular disease }\end{array}$ \\
\hline 18 & 86 & $\mathbf{F}$ & $\begin{array}{l}\text { Pulmonary embolism, myocardial infarction, } \\
\text { previous cholecystectomy }\end{array}$ \\
\hline 19 & 67 & $\mathbf{M}$ & Myocardial infarction \\
\hline
\end{tabular}

TABLE VI

CASES WITH HIGH OXYPHIL CELL SCORES

Case Age Sex Blood Urea Oxyphil Cell Lesion

$\begin{array}{ll}\text { Level } & \text { Grading } \\ \text { (mg./100 ml. })\left(\times 10^{3}\right.\end{array}$ sq. $/$ /gland)

\begin{tabular}{llllll}
\hline 1 & 74 & F & 32 & $2,545 \times 10^{3}$ & $\begin{array}{l}\text { Cerebral tumour, } \\
\text { cholelithiasis } \\
\text { Carcinoma of } \\
\text { thyroid, cholelithi- } \\
\text { asis, coronary } \\
\text { occlusion }\end{array}$ \\
3 & 73 & F & 37 & $28,400 \times 10^{3}$ & \\
4 & 62 & F & 59 & $3,580 \times 10^{3}$ & $\begin{array}{l}\text { Carcinoma of lung } \\
\text { Basilar artery }\end{array}$ \\
thrombosis; \\
chronic diarrhoea \\
of unknown cause \\
Advanced \\
pneumocomosis
\end{tabular}

oxyphil cell areas in excess of $2,000 \times 10^{3} \mathrm{sq} . \mu /$ gland. Five of these have already been listed in Table III as cases of advanced chronic nephritis. Another five in which the blood urea is either normal or slightly raised are recorded in Table VI.

Figure 6 shows the distributions of the cell gradings in a variety of lesions. From this figure it is apparent that the great majority of cases in the categories listed fall below $400 \times 10^{3}$ sq. $\mu /$ gland. Table VII records the number of cases and the 


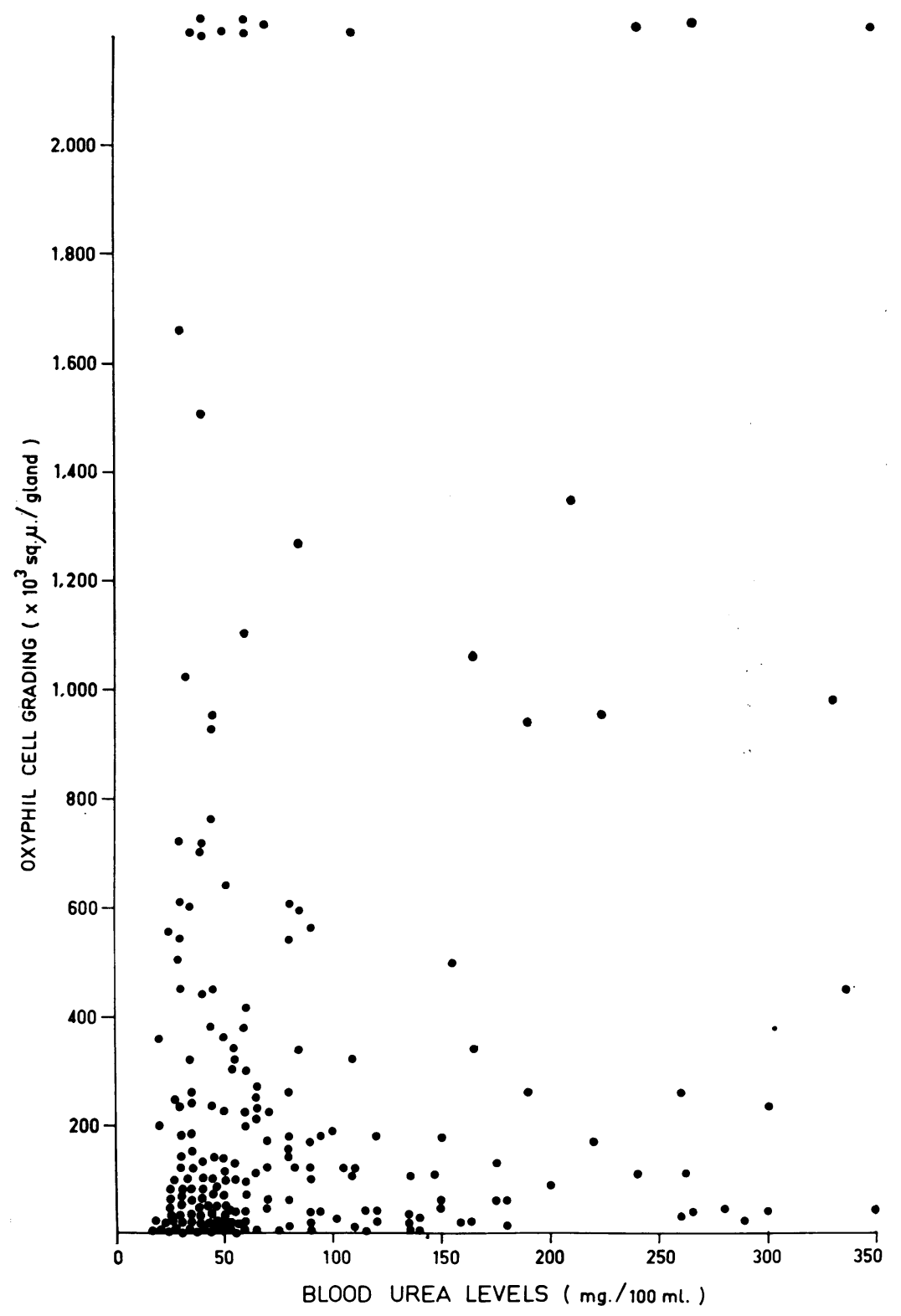

FIG. 5. Distribution of oxyphil cell areas at various blood urea levels.

percentage number of cases in excess of this figure for each sex in each category.

The highest percentage figures belong to five groups, namely, pulmonary embolism, obesity, carcinoma of the lung, cerebral haemorrhage, and cholelithiasis. Over twice as high a percentage of cases described as obese fall above this value as compared with patients recorded as showing generalized wasting.

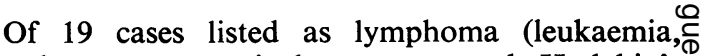
lymphosarcoma, reticulosarcoma, and Hodgkin's $\stackrel{\rho}{?}$ disease) only four rose above $400 \times 10^{3} \mathrm{sq} . \mu /$ gland. 0 Two of these were cases of chronic lymphatico leukaemia, one of lymphosarcoma, and one of follicular lymphoblastoma in a 74-year-old malē complicated by vertebral artery thrombosis. $\frac{\varrho}{\sigma}$ Diabetes, malignant disease in general, peptic ulcer, and cirrhosis of the liver are also at the lower endo 


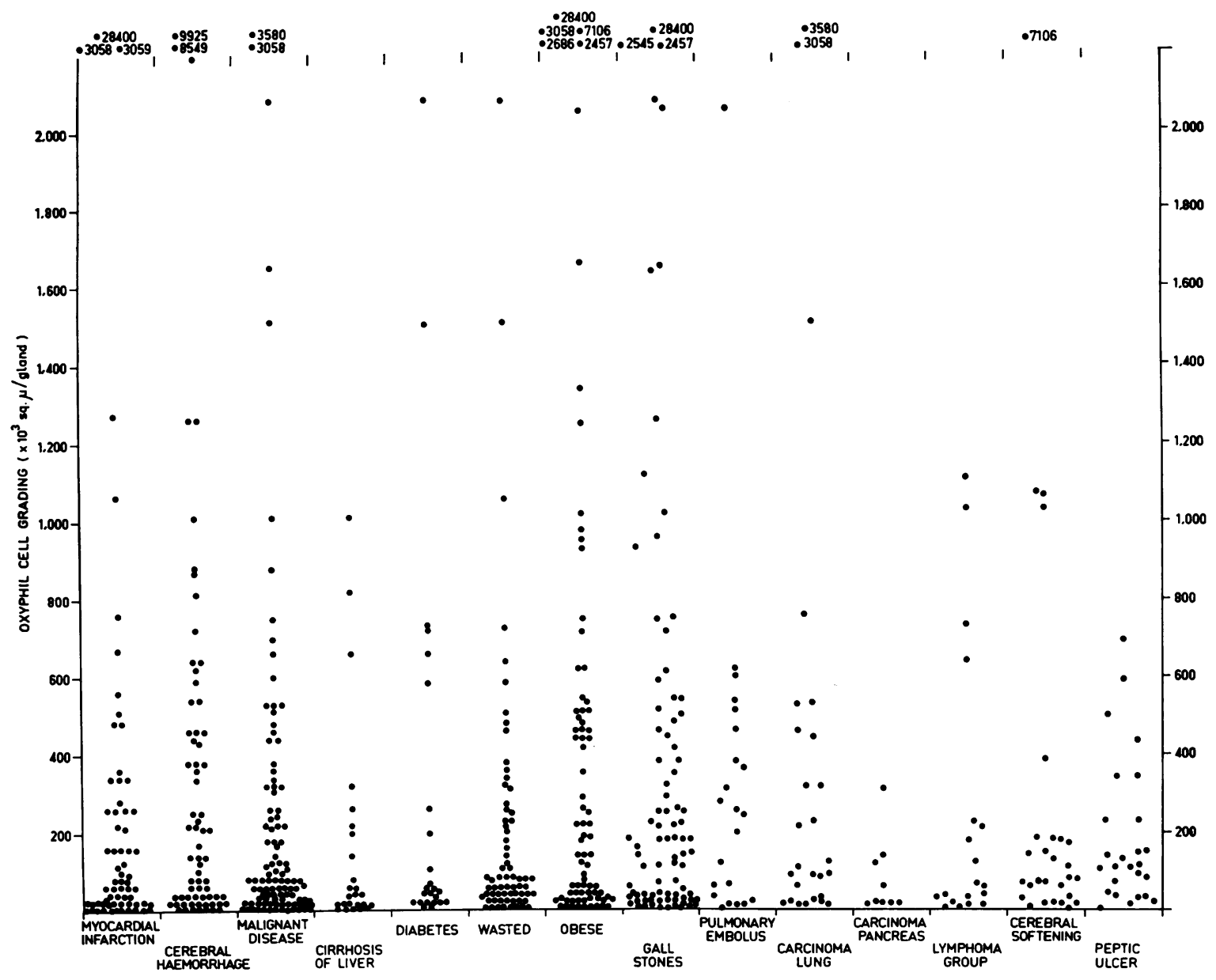

FIG. 6. Distribution of oxyphil cell areas in various pathological states (both sexes combined).

of the scale. Of other disease groups there are insufficient cases.

Five cases of multiple myeloma were examined, all with values below $50 \times 10^{3} \mathrm{sq} . \mu /$ gland. Seven cases of rheumatoid arthritis (six female and one male) showed values ranging from $12 \times 10^{3}$ sq. $\mu$ to 641 $\times 10^{3}$ sq. $\mu /$ gland. Another interesting finding concerned carcinoma of the lung in which eight of 24 males (approximately $33 \%$ ) showed values above $400 \times 10^{3}$ sq. $\mu /$ gland, some being very high. This marked increase is in contradistinction to malignant disease in general. Values for fatal cases of cerebral haemorrhage referred to above range especially high in the case of females.

In the case of myocardial infarction only $9 \%$ of males gave scores above $400 \times 10^{3} \mathrm{sq} . \mu /$ gland. The percentage is considerably higher in females, approaching the percentage for gallstones, obesity, and cerebral haemorrhage. However, the average female age for the 22 cases of myocardial infarction is nine years above the male average.

Although the numbers of cases in each group in Table VII are relatively small, nevertheless they do suggest certain tendencies, especially as the higher percentages of raised gradings occur for the same lesions in each sex (that is, cholelithiasis, cerebral haemorrhage, and obesity). Myocardial infarction is an exception and the cases of pulmonary embolism are too few.

Although more cases in each disease category would be necessary to be absolutely certain of these conclusions they do point to possible significant variations of oxyphil cell grades for different diseases.

In discussing vascular disease it is of interest to note that two cases showing massive intrathoracic 
TABLE VII

VARIATION OF OXYPHIL CELLS IN RELATION TO DIFFERENT CONDITIONS

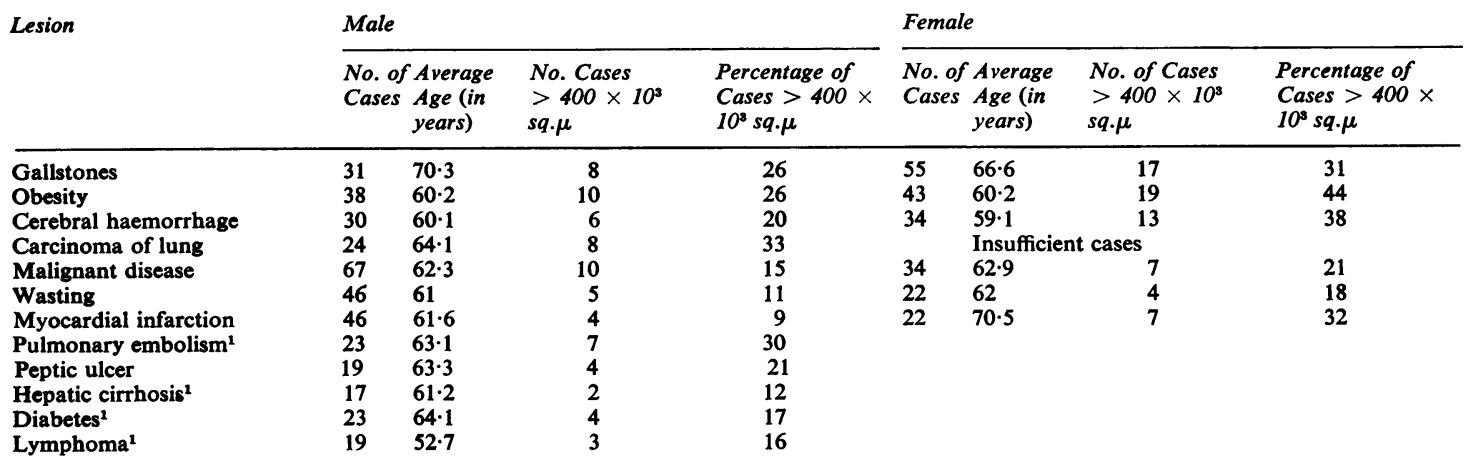

IInsufficient number of cases to divide into sexes

and intraabdominal haemorrhage respectively show pure oxyphil cell hyperplasia without concomitant general glandular hyperplasia.

CASE 3 R.F., a man aged 62 years, had ulcer symptoms for 10 years. On the day of admission to hospital he complained of sudden pain at the level of the fourth thoracic vertebra on the left side. His general condition deteriorated and he died three days after admission. His blood urea level was $47 \mathrm{mg}$. $/ 100 \mathrm{ml}$. The serum transaminase levels (SGOT and SGPT) were normal.

At necropsy there was a massive haemothorax but no evidence of a tear or rupture of the thoracic aorta which showed mild atheromatous changes only. Both kidneys showed no significant pathological lesions. There was an old healed gastric ulcer astride the pylorus.

All four parathyroid glands are normal in size. Histologically there is a moderate amount of enmeshed fat. There is no principal cell hyperplasia. The oxyphil cells are present throughout all four glands in numerous hyperplastic solid clumps devoid of enmeshed fat. The oxyphil score is $954 \times 10^{3}$ sq. $\mu /$ gland.

CASE 4 H.F., aged 57 years, was in perfect health till two days before admission to hospital, when, for no apparent reason he experienced a sharp pain in the back whilst crossing flat rocks during a fishing expedition. Forty-eight hours later he was admitted to hospital in a state of shock.

At necropsy the only significant findings were a massive retroperitoneal haemorrhage which appeared to arise from the upper right side of the abdominal cavity anterior to the right kidney.

Histologically the kidneys show very mild nephrosclerotic changes. Four normal sized parathyroid glands all show solid hyperplastic clumps of pale and dark oxyphil cells giving a score of $2,686 \times 10^{3}$ sq. $\mu /$ gland. There is no principal cell hyperplasia.

Whilst too few to be of significance, it is worth recording that the two following cases, having carcinoma of the thyroid in common, showed high oxyphil scores.
CASE 5 Mrs D., aged 76 years, was an obese woman who presented with symptoms of cardiac failure for three months. Her blood urea level was $30 \mathrm{mg} . / 100 \mathrm{ml}$.

At necropsy she had, in addition to a large number of gallstones and confirmatory evidence of cardiac failure, an invasive papillary carcinoma of the thyroid.

Three parathyroid glands of normal size were located. All three show no evidence of principal cell hyperplasia. However, each shows numerous well vascularized clumps up to $1.0 \mathrm{~mm}$. in diameter of pale and dark oxyphil cells. The oxyphil cell score is $1,915 \times 10^{3} \mathrm{sq} . \mu /$ gland. The kidneys show mild nephrosclerotic changes only.

CASE 6 Mrs. J., aged 73 years, an obese woman with cholelithiasis ( 5 cholesterol stones) had a well-differentiated carcinoma of the thyroid gland with a metastasis in the cranium overlying and compressing the right parietal lobe of the brain. Her blood urea level was $37 \mathrm{mg}$./100 ml., serum calcium $9.8 \mathrm{mg} . / 100 \mathrm{ml}$. and serum magnesium $2.5 \mathrm{mg}$. $/ 100 \mathrm{ml}$.

Four parathyroid glands of slightly increased size were located. The predominant cell is the oxyphil, being grouped in large and small clumps in each gland. There are also several large discrete clumps of water-clear cells. The oxyphil cell score is $28,400 \times 10^{3}$ sq. $\mu /$ gland.

As both cases were in elderly obese females $\frac{7}{O}$ showing cholelithiasis the concomitant presence of carcinoma of the thyroid gland may be incidental. N However, further examination of the oxyphil cells in neoplastic disease of the thyroid gland is warranted.

In this series there were eight cases of carcinoma of the breast in only two of which were the scores above $400 \times 10^{3}$ sq. $\mu /$ gland $\left(440 \times 10^{3}\right.$ sq. $\mu$ and $540 \times 10^{3}$ sq. $\mu$ per gland respectively). Both showed widespread metastases.

One case in this group with multiple metastases in the skeleton and elsewhere showed a rapidly rising serum calcium level.

CASE 7 Mrs. H. was a mildly obese woman aged 52 ? years. Her serum calcium level continued to rise from 8 
$15 \mathrm{mg}$. $/ 100 \mathrm{ml}$. to $29.8 \mathrm{mg} . / 100 \mathrm{ml}$. in the three months preceding death. Her blood urea level eight weeks before death was $55 \mathrm{mg} . / 100 \mathrm{ml}$. Urinary calcium excretion was $0.05 \mathrm{~g} . / 24$ hours.

Four parathyroid glands of normal size were located. They show no evidence of general hyperplasia. Principal cells predominate with an occasional vacuolated principal cell but no water-clear cells. The oxyphil score at $322 \times 10^{3}$ sq. $\mu /$ gland is not appreciably raised.

All nine cases of carcinoma of the pancreas show oxyphil scores averaging less than $100 \times 10^{3}$ sq. $\mu$ l gland with a maximum value of $306 \times 10^{3} \mathrm{sq} . \mu$.

Some of the cases of pulmonary carcinoma show high scores. One case is of particular interest in this respect.

The following is typical of a number of cases of carcinoma of the lung.

CASE 8 G.L., aged 91 years, was a lean emaciated male. Nine months before death his blood urea level was $41 \mathrm{mg}$. $/ 100 \mathrm{ml}$. At necropsy an extensive carcinoma of the right lower lobe bronchus was found. There was no evidence of cholelithiasis.

The kidneys show a very mild degree of nephrosclerosis. All four parathyroid glands show no evidence of general hyperplasia, being of normal size and containing enmeshed fat. Oxyphil cells are present in large numbers in well vascularized nodules measuring up to $1.0 \mathrm{~mm}$. in diameter in each gland. The oxyphil cell score is 1,508 $\times 10^{3}$ sq. $\mu /$ gland.

\section{DISCUSSION}

Since Welsh (1898) first described them in detail the oxyphil cells have been noted frequently in routine histological sections of the parathyroid glands, for there is no difficulty in identification. However, no significance has been attached to them. The two variants, namely pale and dark, oxyphil cells differ quantitatively only, depending on the quantity of granules present in the cytoplasm (Christie, 1955). As each variety is mixed with the other in adenomatous nodules composed entirely of these cells, it is most likely that they represent functional stages in the cycle of secretory activity of an endocrine gland. Furthermore the great majority of such nodules of oxyphil cells are highly vascular with widely patent capillaries filled with blood. This histological feature has always been regarded as a sign of active functional activity in the case of other endocrine glands (Maximow and Bloom, 1948).

These cells have only recently been studied in any detail in animals, notably by Tremblay and Pearse (1959) in monkeys and in human material by Tremblay and Cartier (1961) and by Munger and Roth (1963).

Using dogs, Platt (1951) carried out careful studies of the parathyroids in chronic nephritis with and without lumpy jaw. He reported principal cell hyperplasia but no mention was made of oxyphil cells nor were they present in his illustrations. The author has, however, personally observed them in aged lactating cows' glands.

In the past, various workers have considered that the oxyphil cells may be degenerate forms of the principal cells (see Christie, 1955). However, there is no histological evidence for this assumption. In fact, the reverse is the more likely for the following reasons: -1 The nodules are usually highly vascular. 2 Only occasionally do the cells show evidence of degeneration (vacuolation etc.). 3 They show strong histochemical reactions for phospholipid similar to the pituitary acidophil cells (Christie, 1955). 4 Tremblay and Pearse's (1959) studies of various enzyme systems within the cells do not indicate degenerative changes. Their conclusions are that, by means of cytochemical techniques, it can be shown that the oxyphil cells contain more mitochondria than the principal cells and, in addition, exhibit a high activity for various dehydrogenases associated with the tricarboxylic acid cycle, fatty acid oxidation, glucose metabolism, and electron transport in pyridine nucleotide-linked reactions. These results suggest that oxyphil cells are not involuted cells but highly active elements of the parathyroid gland.

The oxyphil cell granules are fixed by a variety of simple fixatives listed in Table I. These include both protein and lipid fixatives (Baker, 1950). As indicated in the same Table these simple fixatives also preserve the pituitary acidophil cell granules which further resemble the oxyphil cell granules by being well stained with Baker's acid haematin stain for phospholipids. On the other hand the fine granules of the intestinal argentaffin cell, whilst also reacting strongly with Baker's stain, are only fixed by lipid fixatives (formalin and potassium dichromate) and the protein and lipid fixative osmium tetroxide. For these reasons it is very likely the parathyroid oxyphil cell granules are composed of a phospholipid-protein complex. A positive reaction with Luxol-fast blue is further confirmation of the presence of phospholipid.

Tremblay and Cartier (1961) extended the work of Tremblay and Pearse (1959) in monkeys to include a histochemical study of oxidative enzymes in the oxyphil cells of human material both normal and abnormal, the latter consisting of a parathyroid adenoma. They found an intense enzymatic activity particularly of cytochrome oxidase, DPN (diphosphopyridine nucleotide) diaphorase, TPN (triphosphopyridine nucleotide) diaphorase, and of succinic dehydrogenase, contrasting with a weaker reaction 
observed in the chief cells. They also concluded that these findings give support to the hypothesis that the oxyphil cells are not degenerate but metabolically active.

Largely as the result of Trier's (1958) electronmicrographic work in the macaque monkey it is suspected that the granules in the oxyphil cells are mitochondria. Whilst Trier's photomicrographs certainly lend support to this interpretation and, as he himself points out, conform to Palade's (1952, 1953) description of mitochondria, nevertheless Trier is puzzled by the tremendous number of these bodies present throughout the cytoplasm of the oxyphil cell. In fact, as he says, the oxyphil cells virtually represent sacs stuffed with mitochondria which are packed so closely that in some instances they indent one another. He also points out that they are longer (up to $0.35 \mu$ in diameter in contrast to $0.25 \mu$ for chief cell mitochondria). Furthermore, filamentous forms are less common, while plump, rod-shaped forms predominate.

As shown in a previous communication (Christie, 1955) nodules composed of an intimate mixture of pale and dark oxyphil cells certainly occur in human material suggesting a self-contained secretory unit.

In their communication Munger and Roth (1963) show an electronmicrograph of a cell within a human parathyroid gland, tightly packed with rod-shaped bodies having closely packed interdigitating cristae. If all these tightly packed bodies are in fact mitochondria then the parathyroid oxyphil cell is unique in possessing the highest density, in fact the maximum possible density, of mitochondria of any animal cell.

For this reason it would be wise to leave open the question as to whether the numerous phospholipid granules in the oxyphil cell are composed entirely of mitochondria or partly of mitochondria and partly of specialized granules morphologically resembling mitochondria.

Furthermore, if the granules do prove finally to consist of mitochondria it would appear that the specialized endocrine secretion of these cells is, in fact, manufactured within the somewhat larger more specialized and certainly more numerous mitochondria packing these cells.

As the oxyphil cells have never been studied in detail previously in various diseases it is necessary to determine certain normal ranges. Table IV gives an approximate mean for each decade in both sexes. However, there is a wide scatter and approximately $40 \%$ of cases 70 years of age and over show minimal values (less than $100 \times 10^{3}$ sq. $\mu /$ gland.) In both sexes under $\mathbf{4 5}$ years of age these cells are few in number except in advanced renal disease.

From the fifth decade onwards it is apparent that the oxyphil cell score for females averages at least twice the male score for comparable age groups (Table IV).

Although the sex distribution in the total sample $\stackrel{\vec{F}}{\vec{s}}$ of over 500 cases closely approximates a 3:2 ratio 0 in favour of the male yet almost as many females as 흐 males exceed the value $400 \times 10^{3}$ sq. $\mu /$ gland. This $\frac{\bar{c}}{\frac{1}{5}}$ is also the case with the various lesions listed in $\underset{\varnothing}{\overparen{Q}}$ Table VII. As mentioned in further detail later there is also a preponderance of females in reported cases of oxyphil cell adenomata.

Many well documented cases of chronic nephritis $\overrightarrow{\vec{\omega}}$ have been recorded (see review by Christie, 1961). $\stackrel{\omega}{\omega}$ The histological findings in the parathyroid glands are usually summed up as belonging to Gilmour's i (1947) classification type four. In the majority of severe cases coming to necropsy there is variable if enlargement of all glands with principal cell hyper- $\mathscr{C}$ plasia predominating. Many of the principal cells 오 are vacuolated in varying degrees up to ballooned water-clear cells. Hyperplastic nodules of oxyphil $\subseteq$ cells are also present. The cases of advanced renal $<$ disease in this series conform to this pattern. Without $\vec{\bullet}$ exception this oxyphil cell hyperplasia is referred to in case reports without any significance being attached to it (Christie, 1961). It is thus a matter of surprise that the oxyphil cells have been so completely neglected by all workers after having noted their presence in increased numbers.

In the case of chronic nephritis it is difficult to assess the minimum time required to develop oxyphil cell hyperplasia. Claireaux (1953) reported a child aged 8 years with advanced chronic nephritis and with a blood urea nitrogen of $79 \mathrm{mg} . \%$ (or $178 \mathrm{mg} . \%$ when expressed in the usual way), showing well developed osteodystrophy and metastatic calcifica- tion in the heart, lungs, meninges, kidneys, and in the arterial tree (renal arcuate arteries, medium and $\delta$ small pulmonary arteries and media of coronary artery). Despite the youth of the patient oxyphil 윽 cell hyperplasia was clearly evident.

In case 1 reported above, the low-grade azotaemia can be attributed to ureteric obstruction caused by $N$ advanced carcinoma of the cervix. The duration of 5 the mild azotaemia as assessed by blood urea $\mathcal{N}$ estimations can be reasonably accurately determined $\underset{\omega}{N}$ as a maximum period of 18 months or less. Another possibility is that the pure oxyphil cell hyperplasia 0 without any concurrent glandular enlargement or $\mathbb{D}$ principal cell hyperplasia may have been due not to $\stackrel{?}{?}$ renal disease but to some other cause, for example, $\square$ the associated neoplasm or the transposition of one ureter into the large intestine.

At this stage it is appropriate to refer to the $\stackrel{\vec{D}}{\mathbb{Q}}$ variation in the number of oxyphil cells from case to case and especially in cases of hyperplasia. On the reasonable assumption that the average volume of 
each individual oxyphil cell from case to case is approximately the same, it will be seen that in certain diseases, and particularly in chronic renal disease, there is a huge increase in the number of these cells. In case 2 (from Table III) the average area per gland was $62,007 \times 10^{3}$ sq. $\mu$ as compared with cases showing $50 \times 10^{3}$ sq. $\mu$ or less. It will be seen that this is more than a 1,200 -fold increase in two dimensions alone. When the third dimension is considered, the actual proportional increase is huge.

Previous accounts of the number of oxyphil cells have been crudely qualitative at best. Had a method been available for making more quantitative estimates this may well have proved of immense value in such cases as that of McPhaul, McIntosh, Hammond, and Park (1964) where, following renal transplantation in a case of parathyroid hyperplasia secondary to severe renal disease, the blood urea level fell almost to normal levels. Had such a cause come to necropsy months or years later still with normal electrolyte levels it would have been of great value to know what had happened to the oxyphil cells in the intervening period. With the advent of renal dialysis and renal transplantation operations it is all the more important to ascertain the function of the oxyphil cells, which may well exercise control over an electrolyte either normally, or, more likely, as an emergency mechanism brought into play in a situation where gross electrolyte disturbances of a chronic nature are likely to occur. Such a situation occurs, par excellence, in severe renal disease. The findings in this paper confirm this but extend them to show that oxyphil cells are increased in other pathological states where both the blood urea and renal histological picture are normal or only slightly deranged.

The fact that oxyphil cells are normally few in number till the middle of the fifth decade suggests that hyperplasia may represent a compensatory mechanism first brought into play at this stage in life unless renal disease precedes this decade.

The association predominantly with renal disease suggests that oxyphil cell hyperplasia may be an attempt to compensate or introduce a reserve controlling mechanism to re-establish or protect an electrolyte equilibrium which is all-important for physiological reasons. The compensatory mechanism may be independent of chief cell hyperplasia as shown in cases 1 and 2 above where the oxyphil cells are increased in number without either enlargement of the glands or marked reduction in fat, which is usually considered to be the first histological evidence of general hyperplasia (Castleman and Mallory, 1935).

Proliferation, either hyperplastic or neoplastic, of the oxyphil cell components of the parathyroid glands may be subdivided into the following groups, namely:-

1 Oxyphil cell hyperplasia concurrent with principal cell hyperplasia (as in most recorded cases of advanced chronic nephritis and in the cases recorded above);

2 oxyphil cell hyperplasia without principal cell hyperplasia (cases 1 and 2, 5, and 8 above). This group will be referred to again later.

3 Rare oxyphil cell adenomata: in over 500 cases forming this series, a few small adenomatous nodules were noted (Table V). There is no known clinical syndrome associated with such adenomata (see below).

Group 2 above is of great interest. Cases may occur with a normal blood urea level and/or in the absence of histological evidence of significant renal disease (Table VI).

In the above series it is apparent that a considerable number of cases of fatal cerebral haemorrhage show oxyphil cell hyperplasia, particularly in the female when almost $40 \%$ show values greater than $400 \times 10^{3}$ sq. $\mu /$ gland. This clearly implies an underlying vascular lesion.

In this respect it is of interest to note that Moore, Hallman, and Sholl (1938) noted severe vascular changes in certain arteries in calves in severe magnesium deficiency. It is well known that there is a close relationship between calcium and magnesium metabolism. This is certainly so in sheep (Herd, 1965). In many cases of severe renal disease showing oxyphil cell hyperplasia there is nephrocalcinosis. In rats there is a close interrelationship between calcium, magnesium, and potassium. For example, Whang and Welt (1963) showed in these animals that potassium depletion accompanies magnesium depletion. However, in magnesium-depleted rats there is nephrocalcinosis and the intensity of the nephrocalcinosis is greatest in those animals receiving no dietary potassium. Again in rats, Whang, Oliver, McDowell, and Welt (1962) showed that nephrocalcinosis accompanied by hypercalcaemia occurs when the diet is deficient in magnesium. The renal lesions are accentuated if accompanied by a potassium-deficient diet as well.

Metabolic studies, including magnesium and potassium as well as calcium and phosphorus, may well give a clue to the function of the oxyphil cells. Certainly the cellular changes in the parathyroids in chronic renal disease are complex with chief cell hyperplasia, oxyphil cell hyperplasia, and usually nodules of water-clear cells. This complex picture is not seen in those cases of pure oxyphil cell hyperplasia if the blood urea level is normal, or, in the absence of this parameter, provided the renal histological picture is relatively normal. Case 8 is an 
example of pure oxyphil cell hyperplasia in a case of bronchogenic carcinoma.

Pulmonary neoplasms are particularly prone to produce electrolyte abnormalities (Freedman, 1966; Hobbs and Miller, 1966). In this series the average oxyphil cell count for cases of cancer of the lung far exceeds that for neoplasms in general and one third of the cases have a score exceeding $400 \times 10^{3}$ sq. $\mu /$ gland. However, unfortunately no electrolyte abnormalities were noted nor in fact looked for in these cases. Nevertheless, these findings indicate that in all cases of pulmonary carcinoma the parathyroid glands, and particularly the oxyphil cells, should be examined carefully and correlated with electrolyte (magnesium, calcium, potassium, and sodium) abnormalities.

Intestinal neoplasms may also cause electrolyte disturbances, particularly potassium deficiency due to excretion of large quantities of potassium by some tumours. In this series two cases of neoplasms of the large intestine showed marked oxyphil cell proliferation. However, this is insufficient to draw any definite conclusion, but warrants further investigation in future series.

In the case of oxyphil cell adenomata, Table $\mathrm{V}$ shows a female preponderance of $3: 1$. When corrected for an equal number of cases of each sex the ratio is $6: 1$. This is in keeping with the reported cases of adenomata which the author was able to find in the literature, almost all being in females (Christie, 1955). The distribution of lesions found at necropsy is not noteworthy except to say that most cases are recorded as being obese.

The fact that oxyphil cell adenomata are unassociated with any clinical syndrome which might be attributed to excess endocrine secretion lends further support for the contention referred to above that the oxyphil cells may have a defence function producing a hormone necessary for maintaining a normal biochemical milieu in adverse circumstances, in particular in chronic renal disease where gross electrolyte imbalance is likely to occur.

It is thus important to examine the parathyroid glands histologically in as many necropsies as possible. When these findings are correlated both with the other necropsy findings and with adequate electrolyte studies before death it may well give a lead as to what particularlar biochemical and physiological function or functions the oxyphil cells are linked with. The above findings clearly indicate that the cells are not degenerate and that hyperplasia of them is associated with a variety of pathological states besides advanced chronic nephritis. Such studies will almost certainly be most fruitful in elucidating the electrolyte abnormalities associated with chronic renal disease and its treatment, particularly by dialysis and renal transplantation.

\section{REFERENCES}

Anderson, W. A. D. (1953). Pathology, 2nd ed. Mosby, St. Louis. Baker, J. R. (1950). Cytological Technique, 3rd ed. Methuen, London. Castleman, B., and Mallory, T. B. (1935). Amer. J. Path., 11, 1. Christie, A. C. (1955). J. clin. Path., 8, 302.

- (1961). Med. J. Aust., 2, 982.

Claireaux, A. E. (1953). J. Path. Bact., 65, 291.

Freedman, A. (1966). Med. J. Aust., 2, 293.

Gilmour, J. R. (1947). The Parathyroid Glands and Skeleton in Renal Disease. Oxford University Press, London.

- and Martin, W. J. (1937). J. Path. Bact., 44, 431.

Herd, R. P. (1965). Aust. vet. J., 41, 385.

Hobbs, C. B., and Miller, A. L. (1966). J. clin. Path., 19, 119.

McPhaul, J. J., Jr., McIntosh, D. A., Hammond, W. S., and Park, O. K. (1964). New Engl. J. Med., 271, 1342.

Maximow, A. A., and Bloom, W. (1948). A Textbook of Histology, 5th ed., p. 443. Saunders, Philadelphia.

Moore, L. A., Halliman, E. T., and Sholl, L. B. (1938). Arch. Path., 26, 820.

Munger, B. L., and Roth, S. I. (1963). J. cell Biol., 16, 379.

Palade, G. E. (1952). Anat. Rec., 114, 427.

(1953). J. Histochem Cytochem., 1, 188.

Platt, H. (1951). J. comp. Path., 61, 188 and 197.

Sandström, I. (1880). Upsala Läk-Foren. Förh., 15, 441.

Tremblay, G., and Cartier, G. E. (1961). Endocrinology, 69, 658.

-, and Pearse, A. G. E. (1959). Brit. J. exp. Path., 40, 66.

Trier, J. S. (1958). J. biophys. biochem. Cytol., 4, 13.

Welsh, D. A. (1898). J. Anat. (Lond.), 32, 380.

Whang, R., and Welt, L. G. (1963). J. clin. Invest., 42, 305.

-, Oliver, J., McDowell, M., and Welt, L. G. (1962). Clin. Res., $10,257$. 